University of Nebraska - Lincoln

DigitalCommons@University of Nebraska - Lincoln

$12-7-1984$

\title{
The Variability of Holocene Climate Change: Evidence from Varved Lake Sediments
}

Walter E. Dean

U.S. Geological Survey, Denver, CO, dean@usgs.gov

J. Platt Bradbury

U.S. Geological Survey

Roger Y. Anderson

University of New Mexico, ryand@unm.edu

Cathy Barnosky

Carnegie Museum of Natural History, Pittsburgh, Pennsylvania

Follow this and additional works at: https://digitalcommons.unl.edu/usgsstaffpub

Part of the Earth Sciences Commons

Dean, Walter E.; Bradbury, J. Platt; Anderson, Roger Y.; and Barnosky, Cathy, "The Variability of Holocene Climate Change: Evidence from Varved Lake Sediments" (1984). USGS Staff -- Published Research. 315. https://digitalcommons.unl.edu/usgsstaffpub/315

This Article is brought to you for free and open access by the US Geological Survey at DigitalCommons@University of Nebraska - Lincoln. It has been accepted for inclusion in USGS Staff -- Published Research by an authorized administrator of DigitalCommons@University of Nebraska - Lincoln. 


\section{The Variability of Holocene Climate Change: Evidence from Varved Lake Sediments}

Abstract. Varved sediments from a lake near the present forest-prairie border in northwestern Minnesota provide an annual record of climate change for the last 10,400 years. Climate-sensitive mineral, chemical, and biological components show that the mid-Holocene dry interval between 8500 and 4000 years ago is asymmetrical and actually consists of two distinct drier pulses separated by a moister interval that lasted about 600 years. Cyclic fluctuations with periods of several hundred years were abrupt and persistent throughout the Holocene and are most clearly recorded within the two drier pulses.

The mid-Holocene is recognized as a time of unusually warm or dry climate (or both) in Europe and North America $(1,2)$. In Minnesota, prairie vegetation such as grasses (Gramineae) and sagebrush (Artemisia) expanded eastward into forested regions of the state between about 8500 and 4000 years ago as climate became more arid $(3,4)$. This prairie period was drier than at present, but evidence is somewhat equivocal as to whether it was colder or warmer.

Elk Lake is situated in a forested region of Minnesota at the headwaters of the Mississippi River, close to the present forest-prairie border (Fig. 1). Elk Lake is typical of moderately deep $(>20$ $\mathrm{m})$, dimictic, hardwater lakes with $\mathrm{CaCO}_{3}$-rich sediments (marl) that are common in the glaciated regions of the north central and northeastern United States. It differs from most other lakes of this type, however, in that the entire Holocene sediment section has preserved annual layers of sediment (varves). The sediments contain several climate-sensitive components that record variability of climate changes, and the varves provide precise time calibration of the rates and timing of these changes. The presence of varves with climatically sensitive components and the location of Elk Lake in a part of North America with steep climatic gradients today (I) suggested that Elk Lake could provide a high-resolution (annual) paleoclimatic record of the Holocene.

Piston cores of the 20-m varved Holo- 
cene section in the deepest $(30 \mathrm{~m})$ part of Elk Lake (Fig. 1) were collected in 1978 and 1982, providing an annual sediment record of the last 10,400 years. A piston core was also collected in a water depth of $10 \mathrm{~m}$ for the study of shallow-water components, especially ostracods. The littoral core is not varved, but has been correlated with the varved core by geochemical and pollen stratigraphy. Investigations on the biology, mineralogy, and geochemistry of surface sediments in lakes throughout Minnesota, on seasonal variations in water chemistry of Elk Lake, and on seasonal variations in sediment components collected in sediment traps provide the connections between the sediment record, present-day lake processes, and climate.

The bottom waters of Elk Lake become anoxic soon after spring turnover and remain so until fall turnover. This period of anoxia apparently is sufficient to eliminate benthic organisms and permit the preservation of seasonal laminations (varves) in the deepest part of the lake throughout its postglacial history. As Elk Lake aged and matured, it passed through three distinct stages of development that are reflected in the composition and thickness of the varves.

In the early postglacial phase (about 10,400 to 8500 years ago), the varves are simple and consist of sharply defined light gray and dark olive laminae (Fig. 2). The dark laminae contain mainly organic matter, clay, and diatoms. The light laminae consist principally of $\mathrm{CaCO}_{3}$ and lesser amounts of iron- and manganeserich coatings and aggregates.

During the second phase (about 8500 to 4000 years ago), the lake became shallower and slightly more saline as a result of drier prairie conditions. At this time, abundant unweathered clastic materials were transported into the deep part of the lake where our core was collected. The seasonal influx of clastic material dramatically altered the appearance of the varves, reduced the relative abundance of $\mathrm{CaCO}_{3}$, and, during the peak influx, nearly obliterated the varved character of the sediment. Typical varves during this second phase consist of thick, light-gray clastic laminae separated by a thin film or dispersed

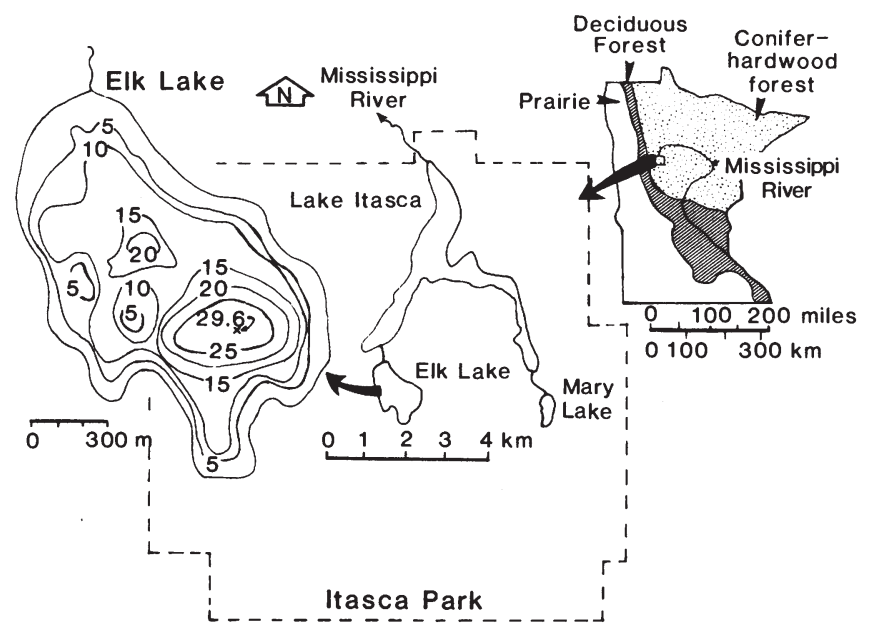

Fig. 1. Maps of Minnesota, Itasca State Park, and Elk Lake showing the location of Elk Lake, general vegetation zones of Minnesota, bathymetry of Elk Lake, and the location of the core site in the deepest part of the lake $(29.6 \mathrm{~m})$. Contour interval of the bathymetric map is $5 \mathrm{~m}$.

Fig. 2. Varve couplets from the lower part of the varve sequence in Elk Lake showing simple sharply defined laminae of clay and diatoms (dark) and $\mathrm{CaCO}_{3}$ (light). Scale in millimeters. zone of dark gray organic-rich material.

During the third and final phase in the development of Elk Lake (about 4000 years ago to present), it returned to a deeper and less saline condition in which very little detrital clastic material reached the core site in the deepest part of the lake. The result is a complex association of autochthonous components, each with a distinct seasonal cycle. The dominant components are diatoms, $\mathrm{CaCO}_{3}$ (Fig. 3), $\mathrm{MnCO}_{3}$, and amorphous flocs and gels of iron and manganese oxides and hydroxides.

Abundances of five selected chemical, mineralogical, and micropaleontological variables plotted as a function of time (varve years) in the Elk Lake core (Fig. 4) illustrate long-term and short-term changes at several different time scales that we believe mainly reflect cyclic variations in climate. Three observations are immediately apparent. First, during the prairie period, between about 8500 and 4000 years ago, conditions were distinctly drier than those either before or after. Second, the prairie period actually consists of two dry pulses separated by a moister interval. The early dry pulse is asymmetrical, with a gradual transition into the prairie period and an abrupt termination about 5400 years ago. The second dry pulse occurred between about 4800 and 4000 years ago. Third, the amplitudes of the climatic oscillations were greatest during the prairie period, with the most pronounced cycles having periodicities of several hundred years. The extremes of these oscillations occurred within several centuries or less, which suggests that significant changes in climate may occur rapidly.

The observations about variability are based on indicators within the lake system (for example, dolomite, sodium, and the diatom Melosira) that are independent of the palynological record. The curve for Artemisia (sagebrush) shows a marked increase in prairie vegetation during the mid-Holocene. If we interpret the relative (percentage) pollen curve of Artemisia (Fig. 4), in terms of climate change, as has been done for numerous sites in North America and western Europe (1), we would conclude that a long period of increased dryness began about 8500 years ago and reached a broad maximum with fluctuations between about 8000 and 4500 years ago; then the climate became wetter and finally stabilized about 3500 years ago.

The amount and composition of clastic materials carried to the lake from the drainage basin and deposited in the deepest part of the lake provide evidence of 
shorter oscillations in climate within the prairie period. Changes in clastic materials are reflected in Fig. 4 as changes in varve thickness, percentage of sodium, and the sodium-aluminum ratio. The sediments deposited in Elk Lake before and after the prairie period consist mainly of autochthonous materials such as diatoms, $\mathrm{CaCO}_{3}$, and iron- and manganeserich organic flocculates. During development of the prairie period, forest cover diminished, water levels in the lake dropped, and clastic materials reached the deepest part of the lake where the core was collected. Variations in varve thickness during this interval are mainly the result of variations in the influx of silt and clay. The smoothed plot of varve thickness (Fig. 4) shows that the prairie period was punctuated by abrupt episodes of clastic influx, with generally fewer than 200 years between minimums and maximums. The varve thickness plot (Fig. 4) also records an episode within the prairie period between 5400 and 4800 years ago when the influx of clastic materials to the deepest part of the lake was reduced. This event is most easily explained by a sudden shift to a higher lake level accompanied by a decrease in the influx of clastic materials to deeper water. After this event, clastic influx returned to high levels for another 1000 years. The prairie period ended about 3800 years ago, when the lake level abruptly rose and the flux of clastic materials was again reduced (Fig. 4).

The episodic influx of clastic materials also is shown as variations in sodium (Fig. 4). Sodium in most lake sediments resides mainly in plagioclase feldspar, which is particularly sensitive to chemical weathering. With abundant available moisture in the drainage basin, plagioclase feldspar weathers rapidly, and sodium remains in solution. The concentration of sodium in lake sediments, and particularly the change in $\mathrm{Na}: \mathrm{Al}$ with time, should provide an index to the degree of chemical weathering in the drainage basin and hence the amount of available moisture in the drainage basin (5). The concentration of sodium, in both the shallow-water core and the varved deepwater core (Fig. 4), increases considerably during the prairie period, as do the concentrations of many other elements associated with the clastic fraction, especially $\mathrm{K}, \mathrm{Ti}, \mathrm{Co}, \mathrm{Cr}, \mathrm{Cu}, \mathrm{Ni}, \mathrm{V}$, $\mathrm{Y}$, and $\mathrm{Zr}$. Other related sediment components that increased during the prairie period are quartz, plagioclase feldspar, and potassium feldspar, all of which indicate that there was increased erosion and decreased chemical weathering during

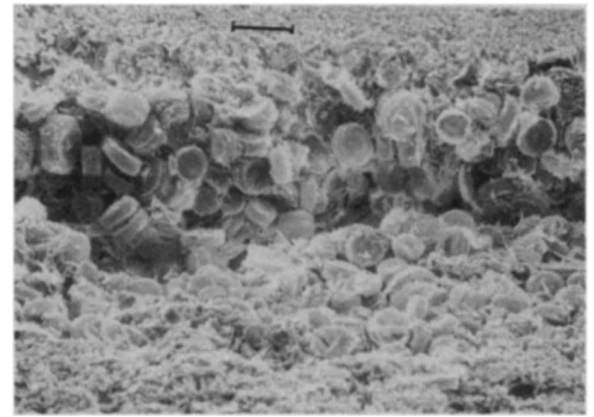

Fig. 3. Scanning electron micrograph of a varve couplet from the upper part of the varve sequence in Elk Lake showing a particularly distinct diatom (Stephanodiscus niagarae) layer and fine-grained $\mathrm{CaCO}_{3}$. Scale bar, 100 $\mu \mathrm{m}$.

the prairie period. The double maximums of clastic influx, separated by an interval of reduced clastic influx, shown by the varve thickness plot, are reflected in the sodium plots for both the littoral and deep-basin cores (Fig. 4). The fact that both cores respond at the same time suggests that the influx of clastic material was general and involved more than resuspension and transport of clastic materials from shallow to deep water.

In contrast to the detrital components, other variables, such as the abundances of dolomite and the diatom Melosira (Fig. 4), record changes in the lake. Surface sediments of lakes in the prairie region of western Minnesota today contain some of the highest concentrations of carbonate minerals of any lakes in Minnesota, but, more importantly, most of this carbonate is high-magnesium calcite and dolomite (6). This is in marked contrast to most other hardwater north temperate lakes in which the carbonate is almost always low-magnesium calcite (7). The increase in dolomite during the prairie period (Fig. 4) indicates that during this period Elk Lake probably acquired chemical characteristics typical of modern prairie lakes in western Minnesota (8).

The dominant diatoms in Elk Lake sediments throughout most of the Holocene varved record (Stephanodiscus minutus and Fragilaria crotonensis) are planktonic forms, which indicates that during the last 10,000 years the lake was never shallow long enough to support a large community of benthic and epiphytic diatoms. However, species of the diatom Melosira dominate the Elk Lake record between 4000 and 5000 years ago, and again between 5400 and 6200 years ago (Fig. 4). These two peak periods of Melosira dominance coincide with episodes of greatest clastic influx. Freshwater planktonic Melosira species apparently require high levels of turbulence to keep the cells from sinking below the photic zone (9). Such turbulence also may be important in supplying large amounts of nutrients to the trophogenic zone to support this diatom. In Elk Lake, Melosira seems to have had a turbulence-nutrient threshold that was not exceeded until about 6500 years ago. However, once Melosira was established in the lake, it responded dramatically to limnological changes. The two

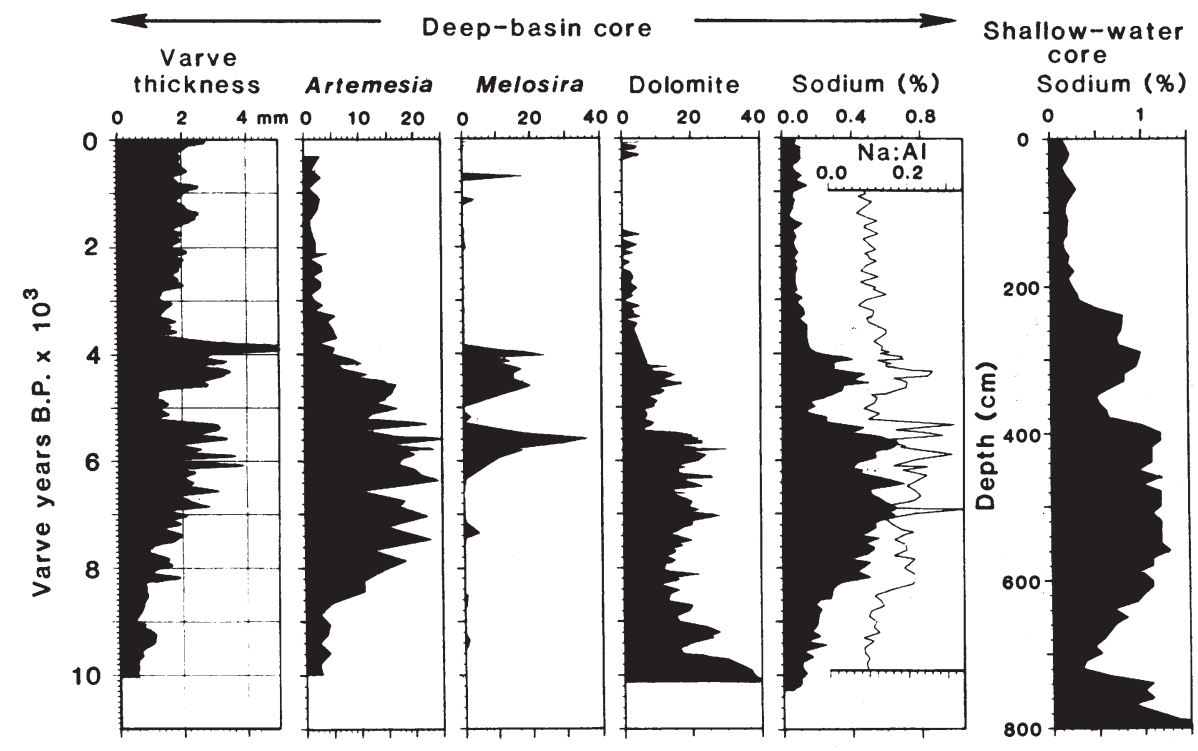

Fig. 4. Plots of varve thickness, percentage of sagebrush (Artemisia) pollen, percentage of the diatom Melosira spp., abundance of dolomite in relative x-ray diffraction peak height, percentage of sodium, and sodium-aluminum ratio as functions of time in varve years before present (B.P.) for the varved core from the deep basin of Elk Lake, and percentage of sodium as a function of depth for a core from shallow water $(10 \mathrm{~m})$. 
periods of increased Melosira abundance suggest periods of relatively low lake level and increased duration and effect of spring circulation and summer turbulence in Elk Lake.

The general climatic model that has been developed for the midwestern United States, largely from studies of past vegetation, is one of gradual increases in warmth and dryness. from about 8500 years ago to maximums about 7000 years ago, and then gradual decreases to more or less present conditions about 4000 years ago (1). In contrast, Bryson et al. (10) argued that Holocene climate was punctuated by rapid transitions between numerous dry and moist periods, each lasting hundreds of years.

The data from the Elk Lake core indicate that between about 8500 and 4000 years ago, climate drier than today's did indeed result in expansion of prairie conditions (for example, increase in grasses and sagebrush in the drainage basin, decrease in decomposition of soil materials, and increase in turbidity and salinity of the lake). During the drier climate of the prairie period, Elk Lake may have resembled the shallow, eutrophic, prairie lakes that exist today south and west of Elk Lake in Minnesota and the Dakotas.

Several sediment components show the long-term shift to prairie conditions, but they also show that the prairie period was punctuated with shorter-term cyclic variations in climatic conditions, with abrupt transitions. These shorter-term cyclic variations are best seen in those variables that monitor changes in the drainage basin, such as sodium (Fig. 4), and in those variables that monitor shortterm changes in the lake, such as dolomite and Melosira. There is evidence, therefore, for both the gradual climate changes of Wright ( 1 ) and the shorterterm, abrupt climate changes of Bryson et al. (10).

The response of paleoclimatic indicators to the beginning and end of the prairie period are not synchronous within the Elk Lake core. Artemisia percentages increase as early as 8800 years ago, preceding the influx of clastic material (measured by varve thickness and percentage of sodium) by at least several hundred years. Similarly, the decline in Artemisia began about 4500 years ago, although the influx of clastic material, and thus higher rates of erosion, persisted until 3800 years ago. This nonsynchroneity may be explained by different responses of the components described here to environmental conditions on different spatial scales. Changes in weathering, erosion, lake chemistry, and dia- tom composition are responsive to changes in conditions in the drainage basin or in the lake. On the other hand, pollen data from a lake the size of Elk Lake probably reflect changes in vegetation over a much larger area (11). Therefore, whereas Artemisia percentages provide a record of regional expansion and contraction of prairie in northwestern Minnesota, other components record the development of open vegetation, unstable slopes, and lower lake levels.

Walter E. Dean
J. Platt Bradbury
U.S. Geological Survey, Federal
Center, Denver, Colorado 80225

Department of Geology,

University of New Mexico,

Albuquerque 87131

CATHY W. BARNOSKY

Carnegie Museum of Natural History,

Pittsburgh, Pennsylvania 15213
References and Notes

1. H. E. Wright, Jr., Quat. Res. (N.Y.) 6, 581 (1976)

2. W. S. Cooper, Geol. Soc. Am. Bull. 69, 941

3. J. McAndrews, Torrey Bot. Club Mem. 22 (1966).

4. D. Stark, Arch. Hydrobiol. Suppl. 50, 208 (1976).

5. F. J. H. Mackereth, Philos. Trans. R. Soc. London Ser. B 250, 165 (1963).

6. W. E. Dean and E. Gorham, Limnol. Oceanogr. 21, 259 (1976); in Quantitative Techniques for the Analysis of Sediments, D. F. Merriam, Ed. (Pergamon, New York, 1976), p. 61

7. K. Kelts and K. J. Hsu, in Lakes-Chemistry, Geology, and Physics, A. Lerman, Ed. (Springer-Verlag, New York, 1979), p. 295; W. E. Dean, Soc. Econ. Paleontol. Mineral. Spec. Publ. 31, 213 (1981).

8. E. Gorham, W. E. Dean, J. E. Sanger, Limnol. Oceanogr. 28, 287 (1983).

9. W. G. Lund, Bot. Zh. (Leningrad) 51, 176 (1966).

10. R. A. Bryson, D. A. Baerreis, W. M. Wendland, in Pleistocene and Recent Environments of the Central Great Plains, W. Dort, Jr., and J. K. Jones, Jr., Eds., (Univ. of Kansas Press, Lawrence, 1970), p. 53.

11. G. L. Jacobson, Jr., and R. H. W. Bradshaw, Quat. Res. (N.Y.) 16, 80 (1981)

12. We thank T. C. Winter, E. J. Cushing, and D. P. Adam for their helpful reviews. Supported by the U.S. Geological Survey Climate Program.

7 June 1984; accepted 17 September 1984 